\title{
The Social Production of Age, Space and Exclusion: Towards a More Theory-Driven Understanding of Spatial Exclusion Mechanisms in Later Life ${ }^{1}$
}

\author{
Thibauld Moulaert, Anna Wanka, Matthias Drilling
}

\begin{abstract}
Gerontology has for a long time been described as "data rich, but theory poor". This is true for the study of spatial exclusion, too: in a recent scoping review on old-age exclusion, Walsh and his colleagues called for more theoretical work in the field of spatial exclusion. To answer this call, our article sketches out a heuristic model of an "ageing, space and exclusion" triangle, mainly based upon Lefebvrian thoughts. We applied our model to interpret the political concept of "Age Friendly Cities and Communities" (AFCC), promoted by the World Health Organization, and its practices worldwide. Some concluding remarks suggest further steps in improving this theoretical perspective.
\end{abstract}

KEY WORDS ageing in place; age-friendliness; Henri Lefebvre; definition of space; social exclusion

\section{Introduction}

In an increasingly globalized world, gerontology's attention turns towards the risks this entails for older adults and the spatial dimension of exclusion in later life (Phillipson 2004). In reference to Walsh, Scharf and Keating's (2017) definition of social exclusion, spatial exclusion can be understood as

A complex process that involves the lack or denial of [spatial] resources, rights, goods and services as people age, and the inability to participate in the normal relationships and activities, available to the majority of people across the varied and multiple domains of society. It affects both the quality of life of older individuals and the equity and cohesion of an ageing society as a whole (adapted from Levitas et al. 2007). (Walsh et al. 2017: 83)

Sociální studia / Social Studies 1/2018. Pp. 9-23. ISSN 1214-813X.

1 This article is inspired by discussions from the "Community/Spatial Working Group" (WG) of the COST-financed Research Network "Reducing Old-Age Exclusion: Collaborations in Research and Policy" (ROSEnet); it has benefited from exchanges from all members of the WG in Oslo (March 2017) and Brno (September 2017). We particularly thank Kieran Walsh and Tom Scharf for their comments and suggestions on the manuscript and their input to the WG. Nevertheless, we assume responsibility for any limitations of this final version. For further details on ROSEnet : www.rosenetcost.com. 
For academic research, globalization increases the need, and the possibilities, for sharing knowledge of different world regions and disciplines. We wish to respond to the recent call for "undisciplining gerontology" (Katz 1996) and the new proposition to consider "ageing studies" as a "region of knowledge" to be discussed and not "taken for granted" (Loffeier, Majerus and Moulaert 2017). Therefore there is a need to strengthen theory in gerontological areas in general (Estes, Biggs and Phillipson 2003), and in the specific domain of spatial exclusion in later life in particular (Walsh et al. 2017).

This article is structured into three parts. First, it presents a review of current literature in gerontology on the spatial dimension related to old age exclusion through four major tasks; even if they are originally inspired by the recent scoping review on social exclusion and older persons by Walsh, Scharf and Keating (2017), these tasks slightly open a broader discussion of literature. Second, it points to some limits that are relevant for our further argumentation. Proceeding from this, the article, third, proposes a way forward to meet this criticism: our "ageing, space and exclusion" triangle is an answer for a more theoretically driven approach to "aging, social exclusion and space". In the last part of the text, a case study is presented about "age-friendliness" embedded into the policy concept and the methodology of "Age Friendly Cities and Communities" (AFCC) promoted by the World Health Organization (WHO) and its practices worldwide (Moulaert and Garon 2016). Concluding remarks suggest further avenues for research to improve our model.

\section{Spatial exclusion in older age: a new research domain with an old tradition}

The discussion about place-based social exclusion is well established and represented by broad research activities with a highly multidisciplinary and intersectoral character. For this reason, research questions, methodologies and field experiences differ greatly (more explicitly cf. Imrie 1996; Levitas 1998; Taket et al. 2009). The debate about age, space and exclusion is significantly younger.

Based on an extensive review of the literature on social exclusion in older age, Walsh and his colleagues (2017) noted that very few papers currently discuss the theoretical dimension of spatial exclusion in later life. This is despite the fact that longstanding traditions in the study and theorising of spatial exclusion exist across different disciplines. As the authors themselves note, their scoping review has some limitations: first, the regional focus on Anglo-Saxon literature; second, the disciplinary focus on gerontological literature; third, a lack of definitions of core terms and concepts like "neighbourhood"; and fourth, denial of the agency of older adults themselves. Taking this scoping review as a starting point, we explore four tasks for the study of spatial exclusion in the following sections.

\section{Task 1: Diversify regional perspectives on spatial exclusion in older age}

Similarly to other researches, focusing on English-language texts only is one major limitation of the scoping review (Walsh et al. 2017) which leads to various consequences. For example, the use of the term "community" as a universal or assumed notion, or the reference to "neighbourhood" which has been critically discussed as a practical illustration of UK 
public policy attempts to create cohesive communities (cf. Evans 2009). It can be questioned whether it is universally accepted that neighbourhood is the central scale of action for public policies in all parts of Europe. More generally, the frequent call to link research and policy, often arising in some areas of critical gerontology, could meet with a problem when trying to translate the local and personal experience of a place into public policy.

Let us consider, for example, the only francophone inspired source (Guberman and Lavoie 2004) in the review. The authors refer to "territorial" rather than neighbourhood exclusion. Both terms cannot be equated: a territoire is a broader term than neighbourhood or community; it is "administrated", and that means that the "production of space" is organized and governed. In the French centralist state tradition, a central authority is delegated to decentralised bodies (départements, and more recently and partially the métropoles). This example indicates that a transnational discussion of the "community and place" dimension of social exclusion might be differently established and that, consequently, the notions of "community" and "space" do not relate to a homogeneous or "taken for granted" understanding as it might appear from interpreting the anglophone literature.

\section{Task 2: Diversify disciplinary perspectives on spatial exclusion in older age}

For decades, gerontology has faced the criticism of being "data rich, but theory poor" (Birren 1999: 459). Hence, much of the gerontological literature on spatial exclusion in later life tends to ignore longstanding traditions of researching spatial exclusion in other disciplines like human geography (e.g. Lawton and Nahemow 1973), environmental psychology (e.g. Wahl and Oswald 2010), and sociology of space (e.g. Lefebvre 1991).

Hence, we want to emphasize the need to explore broader "regions of knowledge", "stepping outside of the gerontological field and discovering beyond the UK, US and Canada other localizations of knowledge production" (Loffeier, Majerus and Moulaert 2017). The work of Henri Lefebvre (1991) is especially valuable for our understanding and may be used not only as a general justification to support the "right to the city" of older people (Buffel, Phillipson and Scharf 2012). Lefebvre introduces his understanding of the production of space early on in his theory of urban development, from which further fundamental urban research work has benefited. According to Lefebvre, place is a product of the dynamic between everyday practices and perceptions of people (spatial practice), cognitive concepts or theories of space (representational space), and the spatial imaginary (representations of space) (Lefebvre 1991).

- Spatial practice refers to the everyday practices and perceptions with which ordinary people encounter and use space. It comprises the daily routines and ways older people follow within their scope of action, the places they avoid, and the ways they appropriate places and attach a feeling of home to them.

- Representational space refers to the passively, instead of actively (see above), experienced space - the way people subconsciously read and understand signs and symbols in space. These symbols help us to tell a road from a sidewalk or a playground from a park, but they also give us clues on where and where not to go, for example via signs of disorder that might symbolise crime in a certain 
area (cf. Kelling and Wilson's “broken windows hypothesis”, 1982). Hence, representational space and spatial practice are closely related.

- Representations of space are the conceptualizations of space made by planners, scientists, and policy stakeholders. The representations may manifest materially in the form of maps, plans, models and designs. Such representations are laden with ideologies and have a substantial role and specific influence in the production of space. In regards to ageing, concepts of age-friendly cities would constitute a case of the representations of space.

We suggest that such concepts would assist in offering a more thorough understanding of the experiences of everyday life of place (spatial practice) in relation to public policies (which are influenced by representations of space). It might also be a starting point for conceptualizing new solutions for the challenges of social exclusion and place (spaces of representation) - for example, Wanka (2018) shows how a public park in a distressed neighbourhood in Vienna can illustrate the dynamic between these logics: an apparently excluded older man who is considered as tramp by social services, is embedded into the local security system of the park and has, by this function, a sense of belonging to the community; similarly, a woman apparently in poor health, from the same area, reveals herself as the historical leader of a local campaign to protect the park against destruction for building a car park.

\section{Task 3: Define core concepts and terms}

Contrary to the tasks of broadening our perspective, we here propose to narrow down in one dimension - namely, the definition of terms and core concepts. Indeed, it might be fruitful not to define such central notions as "community" and "spatial" from a metatheory or based on a positivist perspective. Nevertheless, we suggest that some clear definitions of such terms might be helpful to find a common objective from amongst diverse disciplines and diverse countries and cultures within Europe. Even if apparently very basic, we might consider as a point of agreement with Evans the view that most theories of community focus to varying degrees on three key elements: place attachment, shared interest, and a sense of identity (Evans 2009: 18): for example, we might consider how older people adapt to the changes of a place regarding their longstanding experience of the place, but also based on their shared interest in living there (being recognized by their neighbours) that would create a shared identity of place (the village, the neighbourhood etc.).

Similarly to the concept of community, the notion of exclusion must be reviewed. For example, referring to social segregation instead of social exclusion draws our attention to the structural mechanisms through which people of different status groups are assigned to different neighbourhoods - a process in which the intersectionality of class, ethnicity and age gains importance (Löw, Steets and Stoetzer 2007). If we refer to Sassen's (2014) notion of spatial expulsion, on the other hand, we exceed the meaning of exclusion to describe living conditions that actually make it hard for older adults to survive, and our attention might turn to the most deprived countries in this globalised world. If we talk about spatial deprivation, 
as is more common in the German literature, we are using a relational measurement of exclusion that presupposes a defined standard of living and a continuum on which one deviates more or less from this standard. Hence, as with the notion of community, a precise definition offers different strands of possible research questions to follow.

Task 4: Enhance the relevance of agency in researching spatial exclusion in older age

Fourth, the role of "agency" remains underdeveloped in relation to the "neighbourhood and community" dimension of exclusion. Instead, older adults are often framed as victims of their environments. Arguing with Torres (2015), who makes this claim for gerontological research on ethnicity, most of gerontological research on spatial exclusion follows structuralist approaches, combined with a deficiency perspective on older age. This means that age is defined through loss of resources, which increases older persons' dependency on, or even subjection to, their environment.

Whereas structuralist approaches tend to focus on objective living conditions and their risks, for example through segregation or gentrification, other gerontological research has already turned to the question of how these conditions are perceived, assessed and approached differently by various older individuals or groups of older adults (cf. Kahana 1982). A great body of gerontological research has since targeted the question of subjective place attachment or "feeling at home" or "insideness" (Rowles 1978). This is in line with Evans (2009), who argues, with reference to Lefebvre, that these various perceptions constitute an essential element of the "layered environment" (Peace, Kellaher and Holland 2005). And this is essential to understand how solidarity and the significance of relations at the core of defining community (Clark 1973) encompass emotions, values, and such, as an important part of their definition or articulation.

Furthermore, space is not just perceived. It is also actively constructed and changed. For example, Rowles and Watkins (2003) conceptualise a life-course model of environmental experience. In their experiential phenomenological research, they analyse the dynamic nature and the development of the person-environment relationship across the life course and how the development of this relationship entails the formation of new competences. One of the core competences for building relationships with places is the ability to "make places," which evolves and changes across the life span.

Taking the subjective and practice-based dimension into account should not make us blind to the deprived living conditions of older people who might still feel attached to their neighbourhood ("satisfaction paradox"), but should instead prevent us from assuming any "automatic" or "causal" relation between the various dimensions of space. The distinction between "tactics" and "strategies" is a way to avoid this trap (de Certeau 1984). In order to avoid a container vision of place (or community) as a physical environmental (natural or social), or a more determinist influence of space, a probabilistic vision of space (Remy 2015) is preferred: as space (or community) can influence the life of an individual, thus space could be one element of social exclusion. Assuming a probabilistic approach to the relation between space and ageing, we might consider social exclusion to be a potential, but not automatic, consequence. 
To organize a probabilistic approach, we propose an alternative framework that should be able to grasp the main questions about the structure of the relations between age, space, and exclusion. This approach should be considered an epistemological tool to open broader pathways that might be used more widely by researchers from across Europe, and within the varied, but clearly assumed, tools of diverse reservoirs of knowledge.

\section{A theory-based framework: the ASE triangle}

To encounter the above-described tasks, we propose a heuristic, theory-based framework to look at age and spatial exclusion. The Ageing, Space, and Exclusion (ASE) triangle (Figure 1) is a proposition to grasp the relations between notions of age, space and exclusion, presented as constructive "contradictory terms" or as a variety of levels and scales that have to be taken into account. Lefebvre's differentiation between spatial practice, representational space, and representations of space can be adapted to each of these three dimensions: hence, we cannot only talk about spatial practice, representational space and representations of space, but also about practices of ageing, representational age and representations of age that intersect with those of space to produce practices and representations of spatial exclusion in older age.

Furthermore, as it should not be considered a "fixed box" or a "ticking box" but rather an open access analytical toolbox, it could be useful to embed in scientific disciplines and for policy making purposes. Applied to the notion of age-friendliness in the fourth section (below), we insist on the heuristic usefulness of this model. As a consequence, our case study does not treat all dimensions of this triangle. For example, the "materiality" of space or of community could be discussed with reference to virtuality (e.g. the internet community) and flexibility of work and place (Sennett 1999), but also with reference to time acceleration (Rosa 2010).

\section{Age}

Age encompasses, at least, two very general dimensions. On one side, age diversity, which is related to the extreme heterogeneity of age and ageing. On the other side, age concepts refer to central notions in gerontology, either descriptive (frailty) or normative (active ageing). Researchers are just beginning to explore how and to what extent the individual needs of elderly people are taken into consideration, how the differentiation of lifestyles is included or excluded, and how particular neighbourhood settings affect everyday life. Hagestad and Uhlenberg (2005), for instance, raise the question as to whether the segregation of age groups indirectly promotes exclusion processes. On the other hand, critics claim that the state of knowledge indicates that the planning and policy for age-sensitive neighbourhood development is hindered by persisting concepts about elderly people, and ignorance, as well as visible and invisible age discrimination. In cases where elderly people themselves start to identify as "old" etc., processes of self-segregation might exist and result in situations of exclusion (Vitman, Lecovich and Alfasi 2014). McHugh (2003) points out that the triad of place, society, and image reveals indivisible facets of the social world. He argues, "place-based images and scripts can be interpreted not only 
Figure 1: The ASE Triangle, or the Landscape of contradictions about ageing and community (based on an original idea of Matthias Drilling)

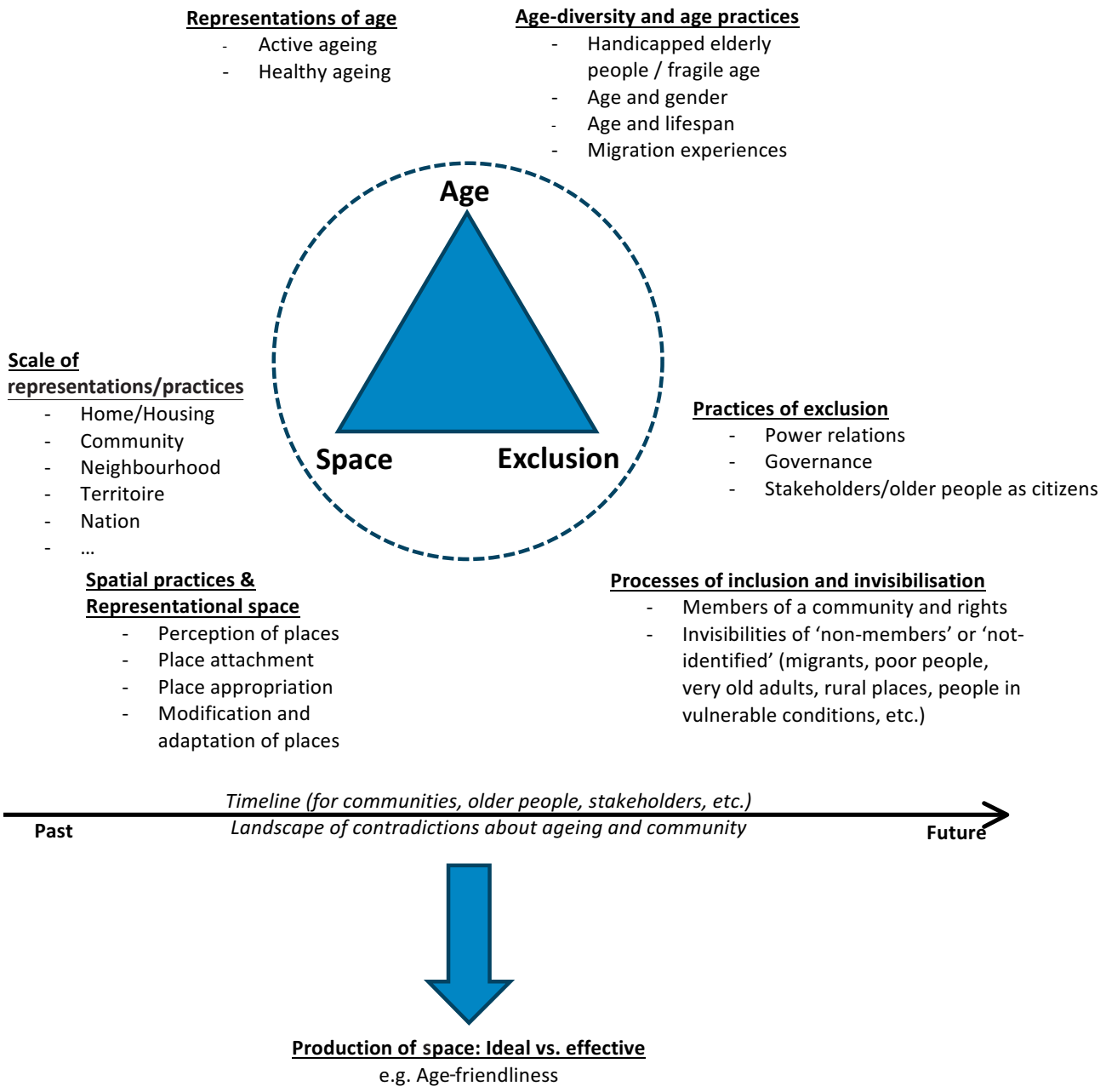

as marketing ploys and strategies but, more deeply, as mould and mirror of ageist attitudes and cultural values" (McHugh 2003: 166).

\section{Space}

We can, at least, assume a common definition of space (from a physical or a social perspective), place (conceived as space and meaning of space), and community (an enduring notion that never seems to disappear in spite of its longstanding critics [Clark 
1973; Stacey 1969]). We can also clarify why the term "neighbourhood" sometimes appears as an equivalent for community (Evans 2009). At this stage, we cannot agree upon common and unique definitions for such concepts.

However, we can repeat the framework suggested in the urban theory of Lefebvre (1991). It states that place is a product of the dynamic between everyday practices and perceptions of people (spatial practice), cognitive concepts or theories of space (representations of space) and the spatial imaginary (spaces of representation). Working within an interdisciplinary perspective, we are also conscious that various disciplines might be more interested in some aspect of each of these definitions behind the concept of space. For example, a psychological perspective of community will probably give more importance to the subjective everyday practices and perceptions of people, i.e. spatial practice (Lefebvre 1991), by distinguishing the environment as private and personal (Peace et al. 2005: 9).

Such notions might not seem as universal as it may sometimes be assumed in the gerontological literature as framed within the Anglo-Saxon context (Loffeier et al. 2017). For example, when referring to community, how close or far are we from the German-based discussion of Gemeinschaft and Gesellschaft of Ferdinand Tönnies (2010)? Scale refers to the variety of levels where the discussion is located. While (Anglo-Saxon) literature originally (Townsend 1962) focused on age-segregated housing (Peace et al. 2005), recently the turn to "ageing in place" gives greater attention to the variety of housing options available in later life, from "age segregated" housing to "ordinary" or "age integrated" housing. Propositions arising from a psychological perspective in gerontology offer a general research agenda in this area (Iwarsson et al. 2007; Wahl, Iwarsson and Oswald 2012).

However, home or housing needs to be considered in relation to other scales like neighbourhood, community, and larger forms of (socio-political or cultural) space like region or nation. In the context of globalization (Phillipson 2004), definitions might cover common trends but also unspecified specificities.

\section{Exclusion}

Exclusion refers to two main dimensions: practices of exclusion (greatly influenced by power relations) and processes of inclusion versus invisibilisation.

Power relations refer to the structural and political dimension of space. The Marxist perspective of Lefebvre, through his triad of production (Lefebvre 1991), insists on power circulation. In critical urban research, urban development is understood as being the result of actions and decisions made by different powerful stakeholders. Social, economic, physical, as well as spatial structures of neighbourhoods and cities are understood as being in constant change and producing relational spatial structures, which in theories of urban development are often referred to as "social space" or "practice of everyday life" (de Certeau 1984; Sennett 1999). Such spaces are understood as being the result not only of human actions, but also as mirroring social relations and being influenced by the wide scope of human action. Referring to de Certeau's work, the "tactics" of consumers of space are never reduced to the "strategies" of producers of space: "the arts of doing," like walking or living 
in a neighbourhood, are forms not only of resistance ("tactics" are never fully determined by "strategies") but also of creative resistance located in time and space.

While such an interpretation can be revisited through analysis of "gentrification" or the influence of globalization on local areas (Phillipson 2004), it can inform us about the new dynamics of community governance; it is also a driver to understand the call to regard older people as citizens, as explored in the study of some local experiences in age-friendly cities and communities (Buffel 2015) and in the general attention paid to older people as co-producers of space or territoires.

Study of the "Inclusion vs. Invisibilisation contradiction" is linked to the notion of community. From a community perspective, place is experienced by members and non-members. As a consequence, and even if "power relations" might encourage the "diversity of ageing" to be taken into account, a series of complementary characterizations of the older population (not as an intrinsic dimension of old age but as a process evolving across the life course) might produce invisibilisation. However, if we adopt an agency perspective for the working definition of social exclusion (as previously cited), a complex question has to be considered: even if access is offered to the visibilisation of older peoples' voices, what is the meaning of "staying at home" or private space (Clément, Mantovani, and Membrado 1996; Smith 2009)?

Beyond the three core notions of our triangle, the final proposition of a timeline arises in reference to the different dimensions of the relations between age, space, and exclusion. For example, "ageing in place" might refer to the different perceptions of time for longstanding inhabitants of a place (Buffel 2012), or for a policy maker promoting gentrification processes in a particular location. At the conjunction of these three notions, and by taking into account the timeline, we can finally consider the Lefebvrian proposition of "production of space" (1991) as a tension between ideal vs. effective.

\section{From theory to empirical studies: towards a better understanding of "age-friendliness" through the lens of the ASE triangle}

Through the three dimensions of the ASE triangle, we here explore the current "age-friendliness" discussion beyond the political concept of "Age Friendly Cities and Communities" (AFCC) promoted by the World Health Organization. It can be considered a general "production of space" between different processes and tensions between "ideal" and "effective" practices of places.

\section{Age}

While a normative dimension of ageing well or active/healthy ageing is assumed in some areas of critical gerontology, and has fuelled the "age-friendly cities and communities" (AFCC) approach of the World Health Organization (WHO 2007), stepping away from ageing studies or gerontology (Loffeier et al. 2017) suggests the need to observe effective practices that reach beyond ideal discourses. Adopted to study the AFCC method, this perspective has offered a material shift (Buffel et al. 2012) and is reflected in the internationally diverse reception 
and/or production of AFCC (Moulaert and Garon 2016). These practices, then, explore how age-diversity is or is not taken into account: for example, even if the original Vancouver Protocol was assumed to have consulted very old people, it seems that such a population was not so often on board (Plouffe, Kalache and Voelcker 2016). In collaboration with local stakeholders in Manchester, another example is offered by Buffel (2015), who trained older volunteers to interview "hard-to-reach" older people (i.e., those experiencing social exclusion, isolation, poverty, health problems, and/or restricted mobility) in the community.

\section{Space}

"Ageing in place" has been an influential notion in ageing policy since the 1990s. Today, it comes along with the notion of age-friendliness. Ageing in place means that ageing happens in a certain spatial environment, and this environment is meant to be the familiar environment of one's own home, community, and neighbourhood, instead of in an unfamiliar, institutional environment. Even if such a scale as "housing" can be included in a spatial dimension like a neighbourhood, it should be clear that the original "Global Age-friendly Cities" project of WHO in 2007 was focussed on cities' scale through (some of their) neighbourhoods; nations or broader territoires were absent. This is essential to understand the shift of WHO, which in its 2015 World Report on Ageing and Health reintroduced the scale of the nation state, through Health Ministers (WHO 2015).

To enable ageing in place, places have to be designed age-friendly. With the increasing political and societal desire that older people maintain independence as long as possible has come the realisation that such independence relies on certain living conditions and one of them is the quality of the residential area. In 2006, WHO launched the "Global Age-friendly Cities" project in 33 cities, resulting in a Global Age-friendly Cities Guide (WHO 2007) and an influential checklist for policy-makers. While this Report and its checklist have been criticized as representing the ideal city (Buffel et al. 2012), with these researchers preferring a more materialistic city, Plouffe and her colleagues (Plouffe, Kalache and Voelcker 2016) have suggested a more balanced perspective by showing the variety of uses of such a checklist. Such a perspective illustrates how the production of space is a continuous negotiation between spatial practice and representations of space.

Another example of the space dimension of our triangle inspired by Lefebvre is the meaning of the public benches in the context of AFCC practices. Indeed, the promotion of benches is often described as a key solution by planners, then mentioned by older people, and potentially selected and put in place by local authorities. Here, benches refer to the practice of space by older people in different ways, and not only to sit and chat. The benches programme also illustrates the representational of space: based on the symbol of active ageing surrounding AFCC, the benches represent a place to stop/wait in the active use of a space, between, for example, home and shops or services. Benches would probably not represent, in this sense, a more romanticised or culturally shaped vision of a bench as a place to sit and relax (Arcand 1982). Finally, the representation of space refers to the conceptions that local planers would promote by placing benches at strategic locations like services and shops. The key point here is to observe that any use of benches in AFCC is always 
a struggle between these dimensions that involve older people (who may ask for the bench or be consulted about its potential use), local stakeholders (who can decide to choose benches as a pragmatic local, and relatively cheap, expense for very tangible and visible effects) and, possibly, planning experts or consultants (who explain what types of benches could be used for older people and/or to implicitly exclude tramps). These struggles produce public space, and the city.

\section{Exclusion}

The centre of public life, as it was shaped in the $18^{\text {th }}$ century, was the metropolis, the capital, the city (Sennett 2008). The cosmopolitan city is, in its imaginary, a space blind to race, class, and gender - it is in fact defined by its diversity, its inclusive dream. Sennett, for example, perceives the focus of urban life on society instead of community as thoroughly positive. As the term res publica comprises the whole network of relations and obligations between people who are not part of one family or community, but of one society, the interest of the city is thus more oriented towards preserving the common good instead of serving particular interests. One of the main characteristics of public space, when seen as equal with urban space, is thus also that it is accessible to all.

Beyond the very essential imagination of the city as urban anonymous space versus the village or neighbourhood as community space, symbolic power plays a role in urban and neighbourhood developments like gentrification, described as the process by which higher income households displace lower income residents in a neighbourhood, changing the essential character and flavour of that neighbourhood (Kennedy and Leonard 2001). The term power relations, like gentrification, describes the process by which economically poor but culturally "rich" population groups (artists, intellectuals, students or the "creative class" in general) move to cheap neighbourhoods, valorising the space with their cultural capital and eventually causing rental prices to rise. Löw (2001: 229) describes the re-shaping of a neighbourhood's image - a core part of gentrification - as the staging of territorial borders to draw clear demarcation lines on an aesthetic level. The symbols that are being used to evoke identification or alienation help to include and exclude groups on a subtler level, as forms of invisibilisation, but nevertheless producing and reproducing inequalities. Such staging processes can also facilitate place identity and place attachment among those who are included; however, they evoke feelings like alienation among those excluded.

\section{Concluding remarks}

Social sciences know many terms for describing unequal life chances: segregation, disintegration, inequality, deprivation, replacement, exclusion, expulsion, marginality to mention but a few. There was a time when cities where perceived as "integration machines" - for example by the famous Chicago School - but today the city is mainly said to have lost this function (Geiling 2003). In contrast to the age-friendliness paradigm presented in the last section, a material discussion of this ideal production of space would refer to the "spatialisation" of social inequalities, that is, the phenomenon whereby 
disadvantaged populations tend to live in disadvantaged areas, and vice versa for privileged populations, which can then be called residential segregation (Savage, Warde and Ward 2003). Residential segregation defines all those processes that eventually lead to internally homogenous spaces that can be based on different social criteria like socio-economic status or ethnicity (Löw et al. 2007). This spatialisation, in turn, affects the life chances of those populations, reproducing social inequalities (Häußermann and Siebel 2000).

By using our ASE triangle, we start answering the four tasks reviewed in the second section. To "diversify regional perspectives on spatial exclusion in older age", we particularly explored the potential of French and German literature on space. To "diversify disciplinary perspectives on spatial exclusion in older age", we presented work by geographers and sociologists. To "define core concepts and terms", and consequently follow the call by Walsh and his colleagues (2017) for more theory of the study of exclusion in old age, inspired by Lefebvre we isolated in a triangle the key contradictions that organize each of the three concepts of ageing, space and exclusion. Eventually, to "enhance the relevance of agency in researching spatial exclusion in older age", we gave examples like the bench to illustrate how the practice of space interacts with representational of space that are always in tension with representations of space.

Our ASE triangle has a heuristic power to propose new research agenda and to pay attention to less explored empirical domains, including attention to public policies. First, as the production of space reveals power relations, it might be fruitful not only to observe or to build participative tools to better take into account older persons, even the "hard-to-reach" ones (Buffel 2015), but to forge a strong methodology to evaluate the real power of these older people and the impact of their voices on public policies. Second, because of longer life expectancy and differentiated lifestyles (including living alone), the number of older adults living with various social ties and, therefore, potentially without strong social support, may increase. In this regard, the role of social services in the local environment should be taken into account, along with peer groups and neighbours. The neighbourhood needs to be understood as a spatial-physical living environment and also as a social setting for participation and support networks and, as such, as fundamental for successfully dealing with everyday life (Drilling and Schnur 2019). Third, the openness of the ASE triangle has the potential to connect debates about age, space, and exclusion from different disciplines and professions and to identify the most relevant issues for local and global political action.

\section{References}

ARCAND, Bernard. 1982. "La construction culturelle de la vieillesse." Anthropologie et Société 6(3): $7-23$.

BIRREN, James E. 1999. "Theories of Aging: A Personal Perspective.” Pp. 459-480 in Handbook of Theories of Aging, edited by Vern L. BENGTSON and K. Warner SCHAIE. New York: Springer.

BUFFEL, Tine. 2012. Experiences of Place and Neighbourhood in Later Life: Developing Age-friendly Communities. Brussels: Vrij Universiteit Brussel. 
BUFFEL, Tine. 2015. Researching Age-Friendly Communities: Stories from Older People as Co-Investigators. Manchester: University of Manchester Library.

BUFFEL, Tine, Chris PHILLIPSON and Thomas SCHARF. 2012. "Ageing in Urban Environments: Developing 'Age-friendly' Cities.” Critical Social Policy 32(4): 597-617.

CLARK, David B. 1973. "The Concept of Community: A Re-examination." The Sociological Review 21(3): 397-416.

CLÉMENT, Serge, Jean MANTOVANI and Monique MEMBRADO. 1996. "Vivre la ville à la vieillesse: se ménager et se risquer." Les Annales de La Recherche Urbaine 73: 90-98.

DE CERTEAU, Michel 1984. The Practice of Everyday Life. Berkeley: University of California Press.

DRILLING, Matthias and Olaf SCHNUR. 2019 (in press). "Neigborhood Development." In The Wiley-Blackwell Encyclopaedia of Urban and Regional Studies, edited by Anthony M. ORUM. New York: Wiley-Blackwell.

ESTES, Carroll, Simon BIGGS and Chris PHILLIPSON. 2003. Social Theory, Social Policy and Ageing: A Critical Introduction. London: Open University Press.

EVANS, Simon. 2009. Community and Ageing: Maintaining Quality of Life in Housing with Care Settings. Bristol, UK: The Policy Press.

GEILING, Heiko, ed. 2003. Probleme sozialer Integration: agis-Forschungen zum gesellschaftlichen Strukturwandel, Soziale Milieus im gesellschaftlichen Strukturwandel. Münster: Lit.

GUBERMAN, Nancy and Jean-Pierre LAVOIE. 2004. Équipe vies: framework on social exclusion. Centre de recherche et d'expertise de gérontologie sociale. Montréal: CAU/CSSS Cavendish.

HAGESTAD, Gunhild O. and Peter UHLENBERG. 2005. "The Social Separation of Old and Young: A Root of Ageism." Journal of Social Issues 61(2): 343-360.

HÄUSSERMANN, Hartmut and Walter SIEBEL. 2000. "Wohnverhältnisse und Ungleichheit." Pp. 120-140 in Stadt und soziale Ungleichheit, edited by Annette HARTH, Gitta SCHELLER and Wulf TESSIN. Wiesbaden: VS Verlag für Sozialwissenschaften.

IMRIE, Rob 1996. Disability and the City: International Perspectives. London: Paul Chapman Publishing.

IWARSSON, Susanne, Hans-Werner WAHL, Carita NYGREN, Frank OSWALD, Andrew SIXSMITH, Judith SIXSMITH, Zsuzsa SZÉMAN and Signe TOMSONE. 2007. "Importance of the Home Environment for Healthy Aging: Conceptual and Methodological Background of the European ENABLE-AGE Project.” The Gerontologist 47(1): 78-84.

KAHANA, Eva 1982. “A Congruence Model of Person-Environment Interaction.” Pp. 97-120 in Aging and the Environment: Theoretical Approaches, edited by M. Powell LAWTON, Paul G. WINDLEY and Thomas O. BYERTS. New York: Springer.

KATZ, Stephen. 1996.Disciplining OldAge: The Formation of Gerontological Knowledge. Charlottesville, VA: University Press of Virginia.

KELLING, George L. and James Q. WILSON. 1982. "Broken Windows: The Police and Neighborhood Safety." Atlantic Monthly 249: 29-38.

KENNEDY, Maureen and Paul LEONARD. 2001. Dealing with Neighborhood Change: A Primer on Gentrification and Policy Choices. Washington, DC: Brookings Institution.

LAWTON, M. Powell and Lucille NAHEMOW. 1973. "Ecology and the Aging Process." Pp. 619-674 in The Psychology of Adult Development and Aging, edited by Carl EISDORFER and M. Powell LAWTON. Washington: American Psychological Association.

LEFEBVRE, Henri. 1991. The Social Production of Space. Oxford: Blackwell.

LEVITAS, Ruth. 1998. The Inclusive Society? Social Exclusion and New Labour. London: Palgrave Macmillan.

LEVITAS, Ruth, Christina PANTAZIS and Eldin FAHMY. 2007. The Multi-dimensional Analysis of Social Exclusion. London: Cabinet Office. 
LOFFEIER, Iris, Benoit MAJERUS and Thibauld MOULAERT, eds. 2017. Framing Age: Contested Knowledge in Science and Politics. New York: Routledge.

LÖW, Martina. 2001. Raumsoziologie. Frankfurt am Main: Suhrkamp.

LÖW, Martina, Silke STEETS and Sergej STOETZER. 2007. Einführung in die Stadt-und Raumsoziologie, UTB Soziologie. Opladen: Budrich.

McHUGH, Kevin E. 2003. "Three Faces of Ageism: Society, Image and Place." Ageing and Society 23: $165-185$.

MOULAERT, Thibauld and Suzanne GARON, eds. 2016. Age-Friendly Cities in International Comparison: Political Lessons, Scientific Avenues, and Democratic Issues. New York: Springer.

PEACE, Sheila, Leonie KELLAHER and Caroline HOLLAND. 2005. Environment and Identity in Later Life. Maidenhead, NY: Open University Press.

PHILlIPSON, Chris. 2004. "Urbanisation and Ageing: Towards a New Environmental Gerontology." Ageing and Society 24: 963-972.

PLOUFFE, Louise, Alexandre KALACHE and Ina VOELCKER. 2016. "A Critical Review of the WHO Age-Friendly Cities Methodology and Its Implementation.” Pp. 19-36 in Age-Friendly Cities and Communities in International Comparison, edited by Thibauld MOULAERT and Suzanne GARON. New York: Springer.

REMY, Jean. 2015. L'espace, un objet central de la sociologie. Toulouse: Érès.

ROSA, Hartmut. 2010. Alienation and Acceleration: Towards a Critical Theory of Late-Modern Temporality. Malmö: NSU Press.

ROWLES, Graham D. 1978. Prisoners of Space? Exploring the Geographical Experience of Older People. Boulder: Westview Press.

ROWLES, Graham D. and Josh WATKINS. 2003. "History, Habit, Heart and Hearth: On Making Spaces into Places.” Pp. 77-96 in Aging Independently: Living Arrangements and Mobility, edited by K. Warner SCHAIE. New York: Springer Publishing Company.

SASSEN, Saskia. 2014. Expulsions: Brutality and Complexity in the Global Economy. Cambridge, MA: The Belknap Press of Harvard University Press.

SAVAGE, Mike, Alan WARDE and Kevin WARD. 2003. Urban Sociology, Capitalism and Modernity, $2^{\text {nd }}$ ed. New York: Palgrave Macmillan.

SENNETT, Richard. 1999. The Corrosion of Character: The Personal Consequences of Work in the New Capitalism. New York: W.W. Norton.

SENNETT, Richard. 2008. Verfall und Ende des öffentlichen Lebens: die Tyrannei der Intimität. Berlin: Berlin Verlag.

SMITH, Allison E. 2009. Ageing in Urban Neighbourhoods. Bristol, UK: Policy Press.

STACEY, Margaret. 1969. "The Myth of Community Studies." The British Journal of Sociology 20(2): 134-147.

TAKET, Ann, Beth R. CRISP, Annemarie NEVILL, Greer LAMARO, Melissa GRAHAM and Sarah BARTER-GOFREY, eds. 2009. Theorising Social Exclusion. London: Routledge.

TÖNNIES, Ferdinand. 2010 [1887]. Communauté et société, translated by Niall BOND and Sylvie MESURE. Paris: PUF.

TORRES, Sandra. 2015. "Expanding the Gerontological Imagination on Ethnicity: Conceptual and Theoretical Perspectives." Ageing and Society 35(5): 935-960.

TOWNSEND, Peter. 1962. The Last Refuge: A Survey of Residential Institutions and Homes for the Aged in England and Wales. London: Routledge.

VITMAN, Adi, Esther IECOVICH and Nurit ALFASI. 2014. "Ageism and Social Integration of Older Adults in Their Neighborhoods in Israel." The Gerontologist 54(2): 177-189. 
WAHL, Hans-Werner and Frank OSWALD. 2010. "Environmental Perspectives on Ageing." Pp. 111-124 in The SAGE Handbook of Social Gerontology, edited by Dale DANNEFER and Chris PHILLIPSON. London: SAGE.

WAHL, Hans-Werner, Susanne IWARSSON and Frank OSWALD. 2012. "Aging Well and the Environment: Toward an Integrative Model and Research Agenda for the Future." The Gerontologist 52(3): 306-316.

WALSH, Kieran, Thomas SCHARF and Norah KEATING. 2017. "Social Exclusion of Older Persons: A Scoping Review and Conceptual Framework." European Journal of Ageing 14(1): 81-98.

WANKA, Anna 2018. "Disengagement as Withdrawal From Public Space: Rethinking the Relation Between Place Attachment, Place Appropriation, and Identity-Building Among Older Adults." The Gerontologist 58(1): 130-139.

WHO. 2007. Global Age-friendly Cities: A Guide. Geneva: WHO.

WHO. 2015. World Report on Ageing and Health. Geneva: WHO.

\section{Authors}

Thibauld Moulaert is Associate Professor at the Université Grenoble Alpes, CNRS, Sciences Po Grenoble, School of Political Studies, PACTE Social Sciences Laboratory, Grenoble, France. His sociological research critically focuses on active ageing and employment in his $\mathrm{PhD}$ at the Université Catholique de Louvain (UCL), on international discourses on ageing in his post-doc, and more recently on the relations between older people, citizenship and environments.

Contact: Thibauld.moulaert@umrpacte.fr

Anna Wanka studied Sociology and Law at the University of Vienna, where she specialized in the role of space and place in the ageing experience. She currently works as a postdoc researcher in the research training group "Doing Transitions" at Goethe University Frankfurt am Main, where she studies the transition from work to retirement and its spatial implications. Contact: Wanka@em.uni-frankfurt.de

Matthias Drilling is social geographer and spatial planner, head of the Institute of Social Planning, Organisational Change and Urban Development at the School of Social Work, University of Applied Sciences Northwestern Switzerland. His research focuses on marginalised groups (esp. elderly people, young adults and homelessness) and sociopolitical strategies of inclusion.

Contact: Matthias.drilling@fhnw.ch 